\title{
Analisis Kandungan Makronutrien Formula Bakso Ikan Lele Dumbo (Clarias gariepinus) dengan Tepung Biji Nangka (Artocapus Heterophyllus)
}

\author{
Tifany Prasaja ${ }^{*}$, Titis Sari Kusuma ${ }^{1}$, Rahma Micho Widyanto ${ }^{1}$, Ilzamha Hadijah Rusdan ${ }^{2}$ \\ ${ }^{1}$ Program Studi Ilmu Gizi, Fakultas Kedokteran, Universitas Brawijaya, \\ Jl. Veteran, Malang, Jawa Timur 65145 \\ ${ }^{2}$ Fakultas Ilmu Tarbiyah, Institut Agama Islam Negeri Surakarta, \\ Jl. Pandawa, Sukoharjo, Jawa Tengah 57168
}

Penulis untuk Korespondensi/E-mail: gabriela.prasaja.29@gmail.com

Abstrak -Kondisi keabnormalan profil lemak yang tinggi secara tidak langsung menggambarkan keadaan dislipidemia. Konsumsi ikan yang masih rendah dan potensi biji nangka yang memiliki kalori rendah dapat dijadikan alternatif makanan rendah kalori berupa bakso ikan. Sebelumnya telah dilakukan uji daya terima formula bakso ikan dengan tepung biji nangka, tetapi komposisi formula tersebut belum sesuai dengan SNI 766:2014. Penelitian ini bertujuan untuk mengetahui kandungan makronutrien produk bakso ikan lele dumbo yang diformulasikan dengan tepung biji nangka, serta mengetahui formula terbaik yang sesuai dengan SNI. Terdapat tiga formula bakso ikan yaitu P0 (25,8\% ikan lele dan 64,5\% tepung tapioka), P1 (25,8\% ikan lele dan 64,5\% tepung biji nangka), dan P2 (45,2\% ikan lele dan $\mathbf{4 5 , 2 \%}$ tepung biji nangka). Ketiga formula dilakukan uji proksimat dengan dua kali ulangan untuk variabel kadar protein, lemak, karbohidrat, kadar abu, kadar air dan serat kasar. Hasil uji ANOVA menyatakan terdapat perbedaan diantara ketiga formula pada semua variabel dan formula yang paling sesuai dengan SNI 766:2014 adalah formula P2 yang mengandung protein 10,35\%, lemak $1,64 \%$, karbohidrat $23,97 \%$ yang setara dengan $151,92 \mathrm{kkal} / 100 \mathrm{~g}$.

Abstract - The abnormality of high fat profiles indirectly illustrates the condition of dyslipidemia. The consumption of fish that still low and the potential of jackfruit seeds that have low calories can be used as alternative low-calorie foods in the form of fish meatballs. Previously, it was tested the acceptability of fish meatball formula with jackfruit seed flour, but the composition of the formula was not in accordance with SNI 766: 2014. This study aims to determine the macronutrient content of African catfish meatballs formulated with jackfruit seed flour, and to find out the best formula according to SNI. There are three fish meatball formulas, namely $P 0$ (25,8\% catfish and 64,5\% tapioca flour), $P 1$ (25,8\% catfish and 64,5\% jackfruit seed flour), and P2 (45,2\% catfish and $45,2 \%$ jackfruit seed flour). The three formulas were carried out by proximate test with two replications for variable levels of protein, fat, carbohydrate, ash content, moisture content and crude fiber. The ANOVA test results state that there are differences between the three formulas on all variables and the formula that best fits SNI 766: 2014 is P2 formula which contains $10,35 \%$ protein, $1,64 \%$ fat, $23,97 \%$ carbohydrate which is equivalent to $151,92 \mathrm{kcal} / 100$ g.

Keywords - Proximate analysis, Catfish meatballs, Dislipidemia, Jackfruit seed flour, SNI.

\section{PENDAHULUAN}

$\mathrm{K}$ ondisi profil lemak penduduk Indonesia di atas 15 tahun menunjukkan bahwa 35,9\% kolesterol total dalam ambang batas dan tinggi, 22,9\% HDL dibawah normal dan lebih dari $22,9 \%$ LDL tinggi [1]. Kondisi tersebut secara tidak langsung menggambarkan kondisi dislipidemia yang merupakan salah satu timbulnya arterosklerosis, penyakit jantung koroner, stroke, sindrom metabolik dan sebagainya. Dislipidemia dapat diawali dengan asupan energi yang berlebih baik dari karbohidrat, protein dan lemak yang 
kemudian disimpan menjadi sel lemak, sehingga profil lemak tubuh meningkat [2].

Pencegahan kondisi dislipidemia dapat dilakukan dengan konsumsi diet rendah kalori dan protein hewani diutamakan berupa ikan [2]. Salah satu jenis ikan yang paling banyak dikonsumsi di tingkat nasional adalah ikan lele [3]. Tetapi ikan lele mudah rusak dikarenakan kandungan airnya yang tinggi [4]. Sehingga perlu pengolahan yang tepat agar lebih tahan lama yaitu menjadi bakso. Olahan bakso dipilih karena dalam proses pembuatannya penggunaan minyak dapat ditiadakan karena proses pembuatannya yang tidak digoreng melainkan hanya direbus.

Pati biji nangka dapat dimanfaatkan sebgai bahan pengisi dalam bakso karena kandungan amilosa yang tidak jauh berbeda dengan tepung tapioka yang biasa digunakan sebagai bahan pengisi bakso [5]. Biji nangka juga memiliki rendaman pati yang lebih besar dibanding dengan biji durian maupun alpukat [6]. Biji nangka juga memiliki energi yang rendah dibandingkan dengan tepung tapioka, tetapi kandungan proteinnya lebih tinggi [7].

Beberapa penelitian telah menggunakan tepung biji nangka sebagai salah satu bahan pembuatan bakso baik bakso ikan maupun ayam. Salah satu penelitian yang telah diuji daya terima konsumen menggunakan formula terbaik dengan $100 \%$ tepung biji nangka sebagai bahan pengisi bakso [8]. Tetapi komposisi formula tersebut belum sesuai dengan SNI 7266:2014, dimana presentase daging ikan hanya $25,8 \%$ yang seharusnya minimal $45 \%$. Sehingga perlu adanya formula yang komposisinya sesuai dengan SNI 7266:2014 tentang bakso ikan. Dalam penelitian tersebut belum dilakukan analisis terhadap kandungan makronutrien pada formula bakso tersebut.

Bakso ikan lele dengan persentase komposisi ikan sebesar 57\% dan $76 \%$ lebih disukai dibandingkan dengan komposisi ikan sebesar 19\% dan 38\% berdasarkan hasil organoleptik panelis terlatih [9]. Pada penelitian lain, hasil daya terima terhadap bakso ikan tuna dengan komposisi tepung biji nangka lebih rendah/sedikit lebih disukai. Kandungan makronutrien bakso dengan komposisi ikan tuna $85 \%$ dan tepung biji nangka $12 \%$ adalah sebesar $17,2 \%$ protein, $5,57 \%$ lemak dan $5,93 \%$ karbohidrat [10].

Penelitian ini bertujuan untuk mengetahui perbedaan kandungan makronutrien bakso ikan lele dengan tepung biji nangka sesuai formula perlakuan kontrol dan terbaik dari penelitian sebelumnya [8] dan satu formulasi yang disesuaikan dengan SNI 7266:2014.

\section{METODE PENELITIAN}

Penelitian ini merupakan penelitian eksperimental lanjutan dengan menggunakan Rancangan Acak Lengkap. Perlakuan berupa tiga formulasi bakso ikan yaitu formula bakso ikan perlakuan kontrol (tepung tapioka $500 \mathrm{~g}$ dan ikan lele $200 \mathrm{~g}$ ) dan terbaik (tepung biji nangka $500 \mathrm{~g}$ dan ikan lele $200 \mathrm{~g}$ ) dari penelitian sebelumnya [8] serta formula modifikasi yang disesuaikan dengan SNI 7266:2014 (tepung biji nangka $350 \mathrm{~g}$ dan ikan lele $350 \mathrm{~g}$ ). Setiap formula perlakuan dilakukan pengulangan sebanyak 2 kali.

Penelitian dilakukan di Laboratorium Diet dan Pangan Fakultas Kedokteran Universitas Brawijaya untuk pembuatan tepung biji nangka dan bakso ikan serta Laboratorium Nutrisi Universitas Muhammadiyah Malang.

\section{Bahan dan Alat}

Bahan yang digunakan dalam penelitian ini yaitu biji nangka salak yang didapatkan dari penjual nangka di jalan Jakarta, kecamatan Klojen - kota Malang dan ikan lele dumbo dari salah satu peternak ikan di Malang. Bahan lain yang digunakan adalah tepung tapioka, tepung terigu, telur, bawang merah, bawang putih, garam dan merica. Bahan yang digunakan untuk analisis kandungan protein antara lain $\mathrm{H}_{2} \mathrm{SO}_{4}$, $\mathrm{NaOH} 60 \%, \mathrm{Na}_{2} \mathrm{SO}_{4} 5 \%, \mathrm{H}_{3} \mathrm{BO}_{3}, \mathrm{HCl} 0.02 \mathrm{~N}$ merek Toray sedangkan bahan untuk analisis kandungan lemak adalah chloroform Emsure dan untuk analisis serat kasar menggunakan $\mathrm{H}_{2} \mathrm{SO}_{4} 1,25 \%, \mathrm{NaOH}$ $3,25 \%$ dan $\mathrm{C}_{2} \mathrm{H}_{5} \mathrm{OH}$ 96\%. Adapun alat yang digunakan adalah panci, pisau, blender, ayakan 100 mesh serta peralatan untuk kegitan analisis makronutrien seperti satu set labu kjeldah dan satu set ekstraktor soxhlet. 


\section{Tahapan Penelitian}

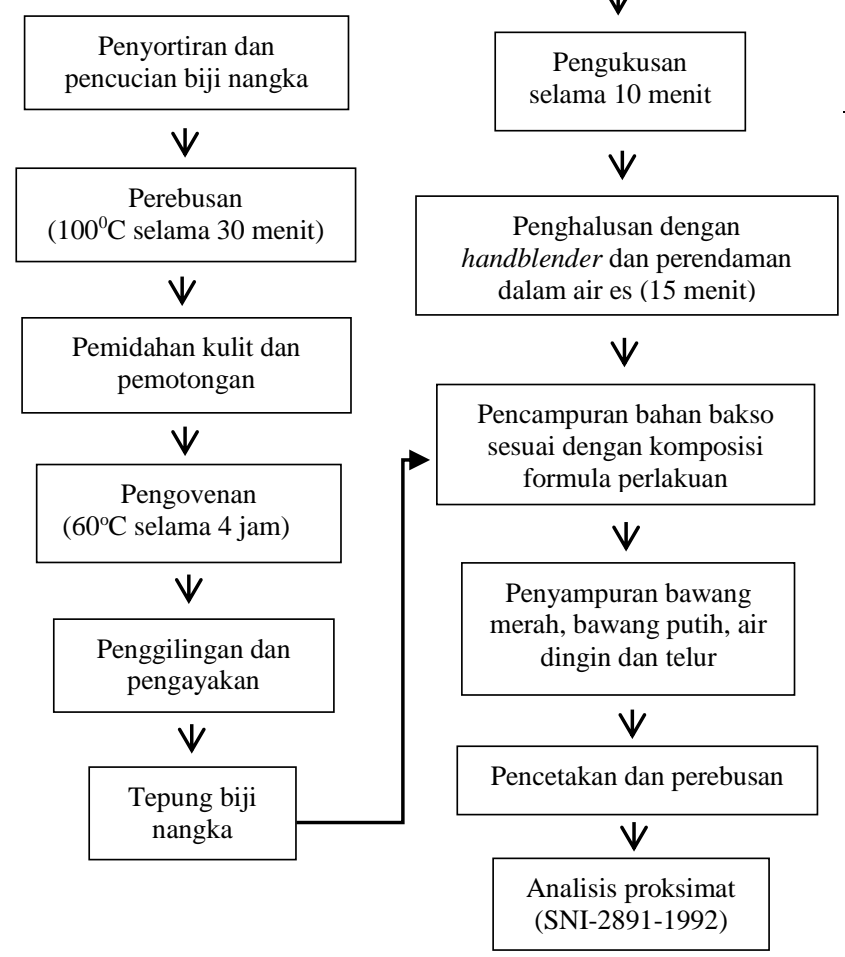

\section{Analisis Data}

Analisis yang dilakukan menggunakan software SPSS 16.0 dengan menggunakan beberapa uji yaitu uji normalitas dan parametrik menggunakan ANOVA. Jika jika hasil yang diperoleh terdapat perbedaan dilanjutkan dengan uji Post-Hoc Tukey untuk mengetahui kelompok yang memiliki perbedaan spesifik.

\section{HASIL DAN PEMBAHASAN}

Hasil analisis proksimat dengan nilai rata-rata seperti pada Tabel 1 menunjukkan adanya perbedaan antar formula yang dilambangkan dengan notasi sebagai berikut.

Tabel 1. Rerata hasil penelitian

\begin{tabular}{cccc}
\hline \multirow{2}{*}{ Kandungan } & \multicolumn{3}{c}{ Rata-rata Nilai Formula } \\
\cline { 2 - 4 } & $\mathrm{P} 0$ & $\mathrm{P} 1$ & $\mathrm{P} 2$ \\
\hline Protein (\%) & $5,23 \pm 0,75^{\mathrm{a}}$ & $9,71 \pm 0,32^{\mathrm{b}}$ & $10,35 \pm 0,27^{\mathrm{bc}}$ \\
Lemak (\%) & $1,32 \pm 0,84^{\mathrm{a}}$ & $7,40 \pm 0,01^{\mathrm{c}}$ & $1,64 \pm 0,07^{\mathrm{ab}}$ \\
$\begin{array}{c}\text { Karbohidrat } \\
(\%)\end{array}$ & $37,23 \pm 0.16^{\mathrm{c}}$ & $27,36 \pm 0,6^{\mathrm{b}}$ & $23,97 \pm 0,04^{\mathrm{a}}$ \\
$\begin{array}{c}\text { Serat Kasar } \\
(\%)\end{array}$ \\
$\begin{array}{c}\text { Energi } \\
(\mathrm{kkal})\end{array}$ & $0,45 \pm 0.06^{\mathrm{a}}$ & $2,82 \pm 0.17^{\mathrm{c}}$ & $1,44 \pm 0,03^{\mathrm{b}}$ \\
\cline { 2 - 2 } & $181,72 \pm 3,96^{\mathrm{b}}$ & $214,86 \pm 1,26^{\mathrm{c}}$ & $151,92 \pm 1,94^{\mathrm{a}}$ \\
\hline
\end{tabular}

\begin{tabular}{|c|c|c|c|}
\hline \multirow{2}{*}{ Kandungan } & \multicolumn{3}{|c|}{ Rata-rata Nilai Formula } \\
\hline & $\mathrm{P} 0$ & $\mathrm{P} 1$ & $\mathrm{P} 2$ \\
\hline $\begin{array}{c}\text { Kadar Air } \\
(\%)\end{array}$ & $55,38 \pm 0,02^{b}$ & $53,72 \pm 0,25^{\mathrm{a}}$ & $62,59 \pm 0,45^{\mathrm{c}}$ \\
\hline $\begin{array}{c}\text { Kadar Abu } \\
(\%)\end{array}$ & $0,85 \pm 0.04^{\mathrm{a}}$ & $1,82 \pm 0,07^{\mathrm{c}}$ & $1,49 \pm 0,06^{b}$ \\
\hline
\end{tabular}

\section{Protein}

Hasil analisis menyatakan bahwa terdapat perbedaan kadar protein antara P0 dengan P1 dan P2. Pada formula P0 tidak menggunakan tepung biji nangka melainkan tapioka, dimana kandungan protein dari tepung biji nangka lebih besar dibandingkan tepung tapioka [11]. Hal ini didukung dengan hasil rata-rata kadar protein P0 lebih rendah dibanding P1 dan P2. Dalam $100 \mathrm{~g}$ tepung tapioka kandungan proteinnya sebesar $0,5 \%$ sedangkan pada tepung biji nangka sebesar $12,19 \%$ [12]. Pada penelitian lain tepung biji nangka dapat dimanfaatkan sebagai sumber protein nabati berupa susu nabati seperti halnya susu kedelai [13].

Pada P1 dan P2 tidak terjadi perbedaan yang signifikan meskipun terdapat perbedaan proporsi antara tepung biji nangka dan ikan lele pada formulasinya. Hal ini dapat disebabkan kandungan protein pada tepung biji nangka yang tidak jauh berbeda dengan daging ikan lele yaitu $17,7 \%$ pada lele dan $12,19 \%$ pada tepung biji nangka [12], dimana pada P1 daging ikan lele lebih banyak $150 \mathrm{~g}$ dibandingkan P2 dan pada P2 tepung biji nangka lebih banyak 150 g. Penelitian sebelumnya menujukkan tidak ada perbedaan yang signifikan antara protein nabati dan hewani terhadap proses perebusan, namun terjadi perbedaan retensi protein (ketahanan suatu bahan terhadap berbagai jenis perlakuan) antara perebusan dan penggorengan dimana retensi pada perebusan lebih tinggi dibandingkan dengan penggorengan [14].

\section{Lemak}

Menurut analisis data kadar lemak terhadap 3 formulasi yang ada, dinyatakan bahwa terjadi perbedaan antara $\mathrm{P} 1$ dengan $\mathrm{P} 0$ dan $\mathrm{P} 2$ dengan ratarata tertinggi terdapat pada $\mathrm{P} 1$ dan terendah pada $\mathrm{P} 0$. Hal ini dapat dikarenakan formula P0 menggunakan tepung tapioka yang lebih rendah kadar lemaknya yaitu sekitar $0,3 \%$ dibandingkan dengan tepung biji nangka yang kadar lemaknya sebesar 1,12\% [12].

Perbedaan antara P1 dengan P2 disebabkan adanya perbedaan komposisi daging ikan lele yang $150 \mathrm{~g}$ lebih banyak pada P2 tetapi tepung biji nangka lebih banyak $150 \mathrm{~g}$ pada P1. Kadar asam lemak tidak jenuh pada lemak hewani lebih sedikit dibandingkan 
lemak nabati. Lemak yang mengandung asam lemak rantai pendek lebih mudah larut dalam air, semakin panjang rantai asamnya maka kelarutan dalam air semakin berkurang [15].

Disisi lain tidak ada perbedaan yang nyata antara P0 dengan $\mathrm{P} 2$ dengan rata-rata formula $\mathrm{P} 2$ lebih besar. Hal ini disebabkan penggunaan tepung tapioka sebanyak 500 g pada P0 dengan kadar lemak 0,3\% dalam setiap $100 \mathrm{~g}$ tepung tapioka dibandingkan tepung biji nangka $350 \mathrm{~g}$ pada $\mathrm{P} 2$ dengan kadar lemak $1,12 \%$ dalam setiap 100 gramnya [12]. Meskipun pada P2 komposisi daging ikan lele lebih banyak $150 \mathrm{~g}$ namun sifat asam lemak tidak jenuh yang terdapat pada lemak hewani lebih mudah larut dalam air [15].

\section{Karbohidrat}

Berdasarkan analisis data kadar karbohidrat dinyatakan bahwa terdapat perbedaan antara formula P0 dengan P1 dan P2 dengan rata-rata tertinggi pada $\mathrm{P} 0$. Hal ini dikarenakan kandungan pada $\mathrm{P} 0$ menggunakan tepung tapioka sedangkan P1 dan P2 menggunakan tepung biji nangka. Dimana kandungan karbohidrat pada tepung tapioka lebih besar yaitu $86,9 \%$ dibandingkan tepung biji nangka yaitu 56,21\% [11]. Tepung tapioka juga memiliki kandungan pati (karbohidrat kompleks yang tidak larut dalam air) sebesar $88,01 \%$, lebih besar daripada tepung maizena $(54,19 \%)$, tepung beras $(25 \%)$ dan tepung ketan yang hanya sebesar $17-23 \%$ [16].

Perbedaan juga terdapat antara P1 dengan P2, dimana rata-rata kadar karbohidrat pada P1 lebih besar. Hal ini dikarenakan pada formula P1 kandungan tepung biji nangka lebih banyak $150 \mathrm{~g}$ dibanding P2. Pada formula P2 $150 \mathrm{~g}$ tepung biji nangka diubah menjadi $150 \mathrm{~g}$ ikan lele sehingga ikan lele yang tidak mengandung karbohidrat tentu akan menghasilkan rata-rata karbohidrat yang lebih rendah dan protein yang tinggi dibandingkan dengan formula P1. Karbohidrat yang lebih rendah pada formula P2 dapat menjadi keuntungan untuk mencegah dislipidemia yaitu dengan menghidari postivie energy imbalance dikarenakan pada kondisi normal, tubuh hanya akan menggunakan karbohidrat sebagai energi utama [17] .

\section{Serat Kasar}

Serat kasar memiliki perbedaan antara formula P0 dengan P1 dan P2. Hal ini dikarenakan pada P1 dan P2 menggunakan tepung biji nangka yang memiliki serat lebih besar yaitu 2,74\% dibandingkan dengan P0 yang menggunakan bahan dasar tepung tapioka yang seratnya hanya $0,1 \%$ [18]. Perbedaan juga terdapat antara formula P1 dengan P2 dimana formula P1 mengandung lebih banyak serat dibandingkan dengan P2. Hal ini dikarenakan formula P1 menggunakan $150 \mathrm{~g}$ tepung biji nangka lebih banyak dibanding P2.

Serat kasar berbeda dengan serat makanan. Serat kasar merupakan residu dari bahan makanan yang tidak dapat terhidrolisa oleh senyawa asam atau alkali. Sedangkan serat makanan merupakan komponen bahan pangan nabati yang tidak dapat dicerna oleh saluran pencernaan baik berupa serat larut dalam air maupun yang tidak larut air. Tetapi serat kasar menjadi penting karena dapat dijadikan indeks atau acuan serat makan, dimana umumnya $0,2-0,5$ bagian serat kasar merupakan serat makanan [19].

Serat erat kaitannya dengan penurunan kadar kolesterol tubuh. Serat akan mengikat asam empedu sesampainya di saluran pencernaan sebelum membantu penyerapan lemak (pengemulsi lemak) yang kemudian akan dikeluarkan berupa feses. Kolesterol akan dirombak untuk menggantikan asam empedu yang hilang tersebut. Sehingga semakin banyak serat yang dikonsumsi maka semakin banyak asam empedu yang dibuang, dengan demikian kolesterol dalam tubuh akan menurun [20]. Terdapat hubungan yang signifikan antara asupan serat dibawah 55,7\% kebutuhan dapat meningkatkan risiko peningkatan kadar kolesterol [21]. Pada penduduk India menunjukkan bahwa konsumsi 3 gram serat mampu menurunkan kadar kolesterol total dan LDL pada penduduk yang mengalami hiperkolesterolemia [22]. Penelitian lain juga menunjukkan konsumsi makanan tinggi serat berupa oatmeal selama 6 minggu dapat menurunkan kadar LDL dan menurunkan risiko kardiovaskuler pada pasien hiperkolesterolemia [23].

\section{Energi}

Terdapat perbedaan kandungan energi antara ketiga formula dengan nilai rata-rata kandungan energi yang terbesar pada P1 dan yang terkecil pada P2. Hal ini dapat dikarenakan energi yang diperoleh berdasarkan konversi nilai makronutrien yaitu protein $4 \mathrm{kkal}$; lemak $9 \mathrm{kkal}$; karbohidrat 4 kkal [24]. Pada P0 protein memiliki nilai terendah, lemak terendah dan $\mathrm{KH}$ tertinggi. Pada $\mathrm{P} 1$ nilai protein dan karbohirat sedang dan lemak tertinggi dengan selisih yang cukup jauh dengan P2 sehingga membuat hasil perhitungan energi menjadi yang tertinggi. Sedangkan pada $\mathrm{P} 2$ nilai protein tertinggi tetapi nilai karbohidrat dan lemak terendah, sehingga membuat nilai energi juga terendah. Pengukuran karbohirat 
dengan metode by different dalam memperkirakan jumlah energi yang diperoleh dari pangan, seringkali memberikan informasi yang salah, saat membedakan jenis karbohidrat yang termasuk available dan non-available (serat) [25].

Makanan dengan kalori yang rendah lebih diminati terlebih bagi seseorang yang menjalankan program penurunan berat badan karena dapat dikonsumsi lebih banyak dibandingkan makanan yang memiliki kalori yang lebih tinggi [26]. Diet rendah kalori juga disarankan dalam Panduan Pengelolaan Dislipidemia di Indonesia berupa buah-buahan, sayur-sayuran, ikan dan daging tanpa lemak [2]. Asupan energi yang tidak dikontrol akan menimbulkan positive energy imbalance yaitu ketidakseimbangan antara energi yang masuk (besar) dan yang dikeluarkan (lebih kecil) yang dapat menyebabkan meningkatnya profil lemak tubuh [27]. Perubahan profil lemak tubuh menjadi abnormal jika berlangsung lama dapat menyebabkan terjadinya kelaianan metabolisme lemak yang merupakan awal mula terjadinya dislipidemia [28].

\section{Kadar Air}

Perbedaan kadar air terdapat antara perlakuan P0 dengan $\mathrm{P} 1$ dengan rata-rata $\mathrm{P} 1$ lebih rendah dibanding P0. Hal ini dikarenakan ukuran diameter granula pati tepung biji nangka lebih kecil dibandingkan tepung tapioka. Dimana semakin besar ukuran granula patinya membuat kemampuan menyerap air semakin besar. Ketika pati dipanaskan dengan air, struktur semi kristal pati akan rusak dan rantai polisakarida akan mengambil posisi acak sehingga menyababkan pati mengembang dan memadat. Disisi lain tapioka mempunyai gugus hidrofil yang mengikat air. Air yang terikat kuat tidak mudah menguap saat dipanaskan [29].

Perbedaan juga terdapat antara P0 dengan P2 tetapi rata-rata kadar air pada $\mathrm{P} 2$ lebih besar dibanding $\mathrm{P} 0$. Pada formula P0 menggunakan tepung tapioka dan pada P2 menggunakan tepung biji nangka yang seharusnya kadar air pada P0 lebih besar akibat ukuran granula pati tepung tapioka lebih besar dibanding tepung biji nangka [29]. Tetapi pada formula P2 menggunakan ikan lele $150 \mathrm{~g}$ lebih banyak dibanding P0 dimana ikan lele memiliki kadar air yang tinggi yaitu sebesar $80 \%$ sehingga kadar air pada P2 lebih besar dibanding P0 [4] .

Perbedaan juga terdapat antara formula P1 dengan P2 dimana rata-rata kadar air P2 lebih besar dibanding P1. Hal ini dikarenakan kandungan protein yang lebih tinggi pada formula P2. Pada suhu tinggi (perebusan) protein lebih mudah terdenaturasi (putusnya ikatan hidrogen yang membentuk struktur heliks) kemudian protein akan berinteraksi dengan air yaitu meningkatkan daya serap air [30]. Tingginya serat pada formula P1 juga menyebabkan rendahnya kadar air dikarenakan serat dapat menyebabkan air terikat lemah [16]. Pada penelitian sebelumnya juga mengalami hal serupa, dimana nilai kadar air semakin rendah terdapat pada bakso ayam yang menggunakan tepung biji nangka lebih banyak dengan komposisi daging ayam sama (serat lebih tinggi) [31].

\section{Kadar Abu}

Terdapat perbedaan kandungan kadar abu dalam setiap formulasi bakso ikan dengan rata-rata tertinggi pada $\mathrm{P} 1$ dan terendah pada P0. Perbedaan antara P0 dengan P1 dan P2 dikarenakan kadar abu pada tepung tapioka lebih kecil dibandingkan tepung biji nangka. Pada tepung tapioka kadar abu sebesar $0,5 \%$ sedangkan pada tepung biji nangka 3,24\% [32]. Perbedaan rata-rata kadar abu pada P1 lebih tinggi dikarenakan pada formula P1 tepung biji nangka yang digunakan lebih banyak $150 \mathrm{~g}$ dibanding P2. Meskipun pada P2 kandungan ikan lele lebih banyak tetapi proses pencucian, pengukusan serta perendaman ikan lele dapat menyebabkan cukup banyak mineral yang larut [33]. Kadar abu lebih tinggi pada formula yang menggunakan tepung biji nangka lebih banyak juga ditunjukkan pada penelitian sebelumnya [8]. Pada bakso ayam, kadar abu juga meningkat seiring dengan penambahan tepung biji nangka [29].

Kadar abu erat kaitannya dengan kandungan mineral, kemurnian dan kebersihan yang terdapat dalam suatu bahan. Pengabuan dapat menyebabkan hilangnya bahan-bahan organik dan anorganik sehingga terjadi perubahan radikal organik dan terbentuk elemen logam dalam bentuk oksida atau bersenyawa dengan ion-ion negatif. Penentuan kadar abu total bertujuan untuk menentukan baik tidaknya suatu proses pengolahan, mengetahui jenis bahan yang digunakan dan dapat dijadikan sebagai parameter nilai gizi suatu bahan makanan [34]

\section{SNI Bakso Ikan}

Pemenuhan syarat mutu kimia ketiga formula bakso ikan berdasarkan 7266:2014 tentang bakso ikan dapat dilihat pada Tabel 2. Tidak terdapat persyaratan terkait kandungan lemak pada SNI 7266:2014 yang sebelumnya ada dalam SNI 013819:1995 yaitu maksimal sebesar 1\%. 
Pada formula bakso ikan lele dengan tepung biji nangka $(\mathrm{P} 0)$ nilai protein kurang dari syarat minimal SNI sedangkan kadar air serta abu sudah memenuhi syarat SNI. Kandungan protein, kadar air dan abu formula P1 dan P2 telah memenuhi syarat SNI dengan kadar lemak lebih tinggi pada formula P1.

Tabel 2. Syarat mutu kimia bakso ikan

\begin{tabular}{|c|c|c|c|c|}
\hline $\begin{array}{l}\text { Mutu } \\
\text { Kimia }\end{array}$ & Regulasi & P0 & P1 & $\mathrm{P} 2$ \\
\hline Protein & $\begin{array}{c}\text { Minimal 7\% } \\
\text { (SNI } \\
7266: 2014)\end{array}$ & $5,23 \%$ & $9,71 \%$ & $10,25 \%$ \\
\hline Lemak & - & $1,32 \%$ & $7,40 \%$ & $1,64 \%$ \\
\hline Kadar Air & $\begin{array}{c}\text { Maksimal 65\% } \\
\text { (SNI } \\
7266: 2014)\end{array}$ & $55,38 \%$ & $53,72 \%$ & $62,59 \%$ \\
\hline Kadar Abu & $\begin{array}{c}\text { Maksimal 2\% } \\
\text { (SNI } \\
7266: 2014)\end{array}$ & $0,85 \%$ & $1,82 \%$ & $1,49 \%$ \\
\hline Karbohidrat & $\begin{array}{c} \pm 25 \% \\
\text { (By Different } \\
\text { SNI) }\end{array}$ & $37,23 \%$ & $27,36 \%$ & $23,97 \%$ \\
\hline
\end{tabular}

Kadar karbohidrat tidak dicantumkan dalam SNI terkait mutu kimia bakso ikan, tetapi apabila dihitung dengan mengacu pada metode karbohidrat by different yaitu pengurangan angka $100 \%$ dengan persentase kombinasi kedua SNI tersebut terkait kadar air, abu dan protein (mengacu pada SNI 2014) serta lemak (mengacu pada SNI 1995) maka kadar karbohidrat sekitar 25\%. Rata-rata kadar karbohidrat pada ketiga formula masih disekitar angka $25 \%$, tepatnya pada P0 sebesar 37,23\%, P1 27,36\% dan P2 23,97\%. Angka $25 \%$ ini bukan merupakan nilai mutlak dikarenakan perhitungan acuan SNI kurang tepat akibat data yang terbatas yaitu kadar protein merupakan nilai minimal sedangkan kadar lemak, air dan abu merupakan nilai maksimal bakso ikan. Sehingga dapat disimpulkan bahwa tidak ada batasan kadar karbohirat pada bakso ikan menurut SNI.

Menurut Panduan Pengelolaan Dislipidemia di Indonesia [2], anjuran diet bagi orang dewasa adalah mengonsumsi diet rendah kalori yang terdiri dari buah-buahan, sayur-sayuran, ikan dan daging tanpa lemak. Sebaiknya konsumsi ikan dan cara pengolahan memanggang, merebus dan mengukus. Diet PUFA omega-3 dapat menurunkan LDL lebih besar dibandingkan dengan diet MUFA atau diet rendah karbohidrat. Peningkatan konsumsi serat juga dianjurkan karena mempunyai efek hipokolesterolemik. Diet serat larut air yang dianjurkan untuk menurunkan LDL adalah sebanyak 5-15 gram/hari [35].

Anjuran diet untuk mencegah dislipidemia dengan diet rendah kalori berupa olahan ikan dan tinggi serat dapat dipenuhi dengan bakso ikan dengan tepung biji nangka. Formula P2 memiliki energi dan lemak yang lebih rendah dibanding P1 tetapi kandungan serat P1 lebih besar dibanding P2. Berdasarkan kandungan yang terdapat dalam ketiga formula bakso ikan, formula yang paling sesuai dengan SNI 7266:2014 baik secara komposisi produk dan persyaratan mutu kimianya, formula P2 dapat dikatakan paling sesuai. Formula bakso ikan P2 mengandung protein sebesar 10,35\%, lemak $1,64 \%$ dan karbohidrat $23,97 \%$ yang setara dengan 151,92 kkal tiap 100 gramnya. Menurut acuan label gizi yang dihitung berdasarkan rata-rata kecukupan energi penduduk Indonesia adalah sebesar $2150 \mathrm{kkal}$ per orang per hari [36]. Secara umum menu makanan yang seimbang dengan komposisi energi dari karbohidrat 50-60\%, protein $10-20 \%$ dan lemak $20-30 \%$ [37]. Proporsi energi untuk makanan utama biasanya sekitar $80-90 \%$ dan berupa snack atau camilan sebesar 20-10\%. Apabila bakso ikan lele formula P2 dengan diameter $\pm 3-4 \mathrm{~cm}$ dijadikan sebagai snack maka pemenuhannya dapat dilihat pada Tabel 3. sebagai berikut.

Tabel 3. Pemenuhan kebutuhan harian 2150 kkal

\begin{tabular}{llcccccc}
\hline Menu & $\begin{array}{c}\text { Berat } \\
(\mathbf{g})\end{array}$ & $\begin{array}{c}\mathbf{U R T} \\
(\mathbf{b j})\end{array}$ & $\begin{array}{c}\mathbf{E} \\
(\mathbf{k k a l})\end{array}$ & $\begin{array}{c}\mathbf{P} \\
(\mathbf{g})\end{array}$ & $\begin{array}{c}\mathbf{L} \\
(\mathbf{g})\end{array}$ & $\begin{array}{c}\text { KH } \\
(\mathbf{g})\end{array}$ \\
\hline $\mathbf{1}$ & $\begin{array}{l}\text { Makanan } \\
\text { utama } \\
(80 \%)\end{array}$ & - & - & 1720 & $43-$ & $38-$ & $215-$ \\
& & & & 86 & 57 & 258 \\
$\begin{array}{l}\text { Snack } \\
(20 \%)\end{array}$ & 283 & \pm 19 & 430 & 29.2 & 4.6 & 67.8 \\
$\mathbf{2}$ & & & & & & \\
$\begin{array}{l}\text { Makanan } \\
\text { utama } \\
(90 \%)\end{array}$ & - & - & 1935 & $48-$ & $43-$ & $242-$ \\
$\begin{array}{l}\text { Snack } \\
(10 \%)\end{array}$ & 142 & \pm 9 & 215 & 14.6 & 2.3 & 34 \\
\hline
\end{tabular}

Keterangan

URT : Ukuran Rumah Tangga

E : Energi

$\mathrm{P}$ : Protein

L : Lemak

$\mathrm{KH}$ : Karbohidrat

Porsi dalam ukuran rumah tangga (URT) sebagai snack bakso ikan lele formula P2 tidak jauh berbeda dibanding produk bakso ikan yang juga menggunakan tepung biji nangka lainnya. Salah satu produk sejenis yaitu bakso ikan tuna dengan tepung biji nangka yang memiliki kandungan 17,2\% protein, 5,57\% lemak dan 5,93\% karbohidrat [10]. Produk bakso ikan tuna tersebut apabila dijadikan 
snack dengan kandungan energi setara dengan bakso ikan lele formula P2 dapat berupa \pm 10 -20 butir bakso dengan ukuran yang sama.

\section{KESIMPULAN}

Formula bakso ikan lele substitusi tepung biji nangka dengan komposisi ikan $45 \%$ merupakan formula yang paling sesuai dengan SNI 7266:2014 tentang bakso ikan, baik secara komposisi produk dan persyaratan mutu kimianya dengan kandungan protein $10,35 \%$, lemak $1,64 \%$ dan karbohidrat $23,97 \%$ yang setara 151,92 kkal tiap 100 gramnya

Anjuran konsumsi bakso ikan lele substitusi tepung biji nangka dengan komposisi ikan $45 \%$ sebanyak \pm 9-18 biji dengan diameter $\pm 3-4 \mathrm{~cm}$ dapat memenuhi 10-20\% kebutuhan energi $2150 \mathrm{kkal}$ dalam sehari

\section{REFERENSI}

[1] Kemenkes RI, "Riset Kesehatan Dasar (RISKESDAS) 2013. Laporan Nasional 2013," Kemenkes RI, Jakarta, 2013.

[2] P. M. Arsana, R. Rosandi, A. Manaf, A. Budhiarta, H. Permana, K. W. sucipta, D. Lindarto, S. Adi, B. Pramono, D. S. Harbuwono, A. Shahb, Sugiart, J. Karimi, L. B. Purnmo and T. S. Ags Yuwomno, Panduan Pengelolaan Dislipidemia di Indonesia, Jakarta: PB PERKENI, 2015.

[3] Departemen Kesehatan, "Ikan untuk Ketahanan Pangan dan Gizi Nasional," Departemen Kesehatan, 2015. [Online]. Available: www.gizi.depkes.go.id. [Accessed 24 Oktober 2017].

[4] I. Rohimah, E. Sudaryati and E. Nasution, "Analysis of Energy and Protein Acceptability Test of Biscuit Pumkin Yellow and Catfish [Skripsi].," FKM USU, Sumatera, 2013.

[5] M. Irwansyah, "Penentuan Konsentrasi Optimum Alumunium Biji Nangka sebagai

Bahan Penghancur Internal Tablet Parasetamol dengan Metode Granulasi [Skripsi]," Poliklinik UHAMKA, Jakarta, 2010.

[6] R. H. Kusriani, I. Rahmawati and I. Musfiroh, "Karakterisasi Pati Biji Buah Duriaan, Biji Buah Nangka, Dan Biji Buah Alpukat," Jurnal Farmasi Galenika, vol. 1, no. 1, 2009.
[7] Direktorat Gizi Depkes RI, Kandungan Nutrisi Biji Nangka, Jakarta: Bhatara Karya Aksara, 2009.

[8] A. M. Salanggon, Finarti and W. A. Tanon, "Karakteristik Nilai Sensori Bakso Ikan Lele dengan Formula Tepung Tapioka dan Tepung biji nangka," in Semnas Kelautan dan Perikanan III, 2017.

[9] Musdalifah and A. T. Wendy, "Tingkat Penerimaan Konsumen terhadap Bakso Ikan Lele dengan Konsentrasi Daging yang Berbeda," Journal of Fisheries, Marine and Aquatic Science, vol. 1 no. 1, pp 13-18, 2016

[10] Yunarni, "Studi Pembuatan Bakso Ikan dengan Tepung Biji Nangka (Artocarpus heterophyllus Lamk). (Skripsi)," FP Universitas Hasanuddin, Makasar. 2012.

[11] S. B. Swim, N. J. Thakor and P. M. H. a. S. B. Kalsel, 2012, Jackfruit and it's many fuctional Component as Related to Human Health [Review].

[12] N. A. Esti and H. Irul, "Analisis Proksimat pada Tepung Biji Nangka (Artacopus Heterophyllus Lamk.)," KLOROFIL, vol. 1, no. 1, pp. 32-37, 2017.

[13] E. A. P. Dennis, "Pemanfaatan Biji Buah Nangka sebagai Bahan Baku Pembuatan Susu Nabati dengan Penambahan Perisa Jahe [Skripsi]," Universitas Sanata Dharma, Yogyakarta, 2017.

[14] A. D. Suhandari and L. Astuti, "Effect of Cooking Process of Composition Nutrional Subtances Some Food Ingredient Protein Source," Media Litbangkes, vol. 25, no. 4, pp. 235-242, 2015.

[15] C. F. Mamuja, LIPIDA, Manado: Unsrat Press, 2017.

[16] E Septiani; S Riswita; dan D Wanti, "Pengaruh Komposisi Tepung Tapioka,terhadap Kualitas Rengginangdari Ampas Tahu Beberapa Varietas Kedelai," in Seminar Nasional Inovasi Teknologi Pertanian Banjarbaru, Banjarbaru, 2016.

[17] N. Wijayanti, Fisiologi Manusia dan Metabolisme Zat Gizi, Malang: Universitas Brawijaya Press, 2017.

[18] Badan Standarisasi Nasional, Tapioka SNI 3451:2011, Jakarta: Badan Standar Nasional, 2011.

[19] R. Yenrina, Metode Analisis Bahan Pangan dan Komponen Bioaktif, Padang: Andalas University Press, 2015. 
[20] Nelm, Marcia, Sucher, Chateryn, Lacey, Karen and R. S. L, Nutrition Therapy and Pathofisiologis. Second Edition, USA: Yolando Casio, 2011.

[21] N. K. Wardani, N. M. Dewantari, K. I. Purnami and P. A. G. Prasanti, "Hubungan Asupan Lemak dan Serat dengan Kadar Kolesterol pada Penderita Diabetes Militus Tipe 2," Jurnal Ilmu Gizi: Journal of Nutrition Science, vol. 7, no. 2, pp. 35 - 41, 2018.

[22] S. Gulati, A. Misra and R. M. Pandey, "Effect of $3 \mathrm{~g}$ of soluble fiber from oats on lipid levels of Asian Indians-a randomized controlled, parallel arm study," Lipid Health Dis, vol. 16, no. 1, pp. 1-8, 2017.

[23] J Zhang; L Li; P Song; C Wang; Q Man; L Meng; J Cai; A Kurilich, "Randomized Controlled Trial of Oatmeal Consumption Versus Noodle Consumption on Blood Lipids of Urban Chinesse Adults with Hypercholesterolemia," Nutrition Journal, vol. 11, no. 1, 2012.

[24] R. Ramayulis, Diet untuk Penyakit Komplikasi, Jakarta: Penebarplus, 2016.

[25] C. M. Kusharto, "Dietary Fiber and Its role for Health," Jurnal Gizi dan Pangan, vol. 1, no. 2, pp. 45-54, 2016.

[26] Detikfood, "Pilih Makanan Rendah Lemak dan Kalori agar Tubuh Kembali Ramping," detik.com, Jakarta , 2013.

[27] D. Handayani, O. Anggraeni and dkk, Asupan Makanan dan Diet, Yogyakarta: Trans Medika, 2016.

[28] Y. H. Effendi, Patofisiologi Gizi, Bogor: IPB Press, 2013.
[29] F. K. Astuti and Y. A. Tribudi, "Penambahan Pati Biji Nangka Terhadap Kualitas Kimia Bakso ayam," Jurnal Teknologi Pertanian, vol. 8, no. 2, pp. 33-39, 2017.

[30] CL Dias; T Ala Nissila; J Wong-ekkabut; I Vattulainen; M Grant; M Karltunen, "The Hydroponic Effect and Its Role in Cold Denaturation. Cryobiology,," Cryobiology, vol. 60, no. 1, pp. 91-99, 2010.

[31] D. N. Saraswati, D. Rosyidi and A. S. Widati, "Substitution of Cassava Strach with Jackfruit Seed Strach (Artocarpus heterophyllus Lamk) on the Physical of Chicken Meatballs. (Skripsi)," FAPET UB, Malang, 2012.

[32] M. K. Mahmud, "Tabel Komposisi Pangan (TKPI)," PT Elex Media Komutindo, Jakarta, 2009.

[33] D. D. Kusumawati, B. S. Amanto and D. R. A. Muhammad, "Pengaruh Perlakuan Pendahuluan dan Suhu Pengeringan Terhadap Sifat Fisik , Kimia dan Sensori Tepung Biji Nangka," Jurnal Teknosains Pangan, vol. 1, no. 1, pp. 41-48, 2012.

[34] F. G. Winarno, Kimia Pangan dan Gizi, Jakarta: PT Gramedia Pustaka Utama, 2009.

[35] PERKI, Panduan Tata Laksana Dislipidemia, Jakarta : PP Perki, 2017.

[36] BPOM, "Acuan Label Gizi. PPBPOM No 9 Bab III (Persyaratan ALG) pasal 4 ayat 1," 2016.

[37] BPOM, "Mengenal angka Kecukupan Gizi (AKG) bagi Indonesia. InfoPOM-Vol 15 No 4," 2014. 